\title{
Perioperative results of mechanical valve implantantation in patients with acquired valve disease
}

\author{
J Konstanty-Kalandyk*, J Piatek, P Babiarczyk, M Medrzycki, L Janik, J Sadowski \\ From 23rd World Congress of the World Society of Cardio-Thoracic Surgeons \\ Split, Croatia. 12-15 September 2013
}

\section{Background}

The implantation of an mechanical valve in many cases remains the best treatment option for acquired valve disease. Mechanical valves, despite necessity of chronic anticoagulation, has excellent durability and favorable hemodynamic parameters. The aim of our study was to evaluate the perioperative mortality in patients undergoing implantation of a mechanical valve and identifying risk factors of death.

\section{Methods}

1500 patients underwent mechanical valve replacement. The analysis included 960 after aortic (AVR), 455 mitral (MVR) valve surgery. Mean age in AVR was $58.7 \pm 13.0$ years and $59.4 \pm 9.0$ years in MVR. Over 70 years of life in AVR was $22 \%$ and $13 \%$ in MVR.

\section{Results}

After mechanical aortic valve perioperative mortality was $1.95 \%$ (stenosis $-1.9 \%$, insufficiency $-2.4 \%$ ) and after mechanical mitral valve was $1.97 \%$ (stenosis $-1.6 \%$, insufficiency- $2.75 \%$ ). Mortality in the age groups $<50$ years, $50-60$ years, $60-70$ years and $>70$ years amounted for mechanical aortic valve $1.6 \%, 1.0 \%, 1.7 \%$ and $3.2 \%$ and for mechanical mitral valve $1,8 \%, 2.8 \%, 1.8 \%$ and $0 \%$ respectively. In patients with aortic stenosis greatest mortality was observed after 70 years $(3.0 \%)$, similarly in aortic regurgitation ( $>70$ years $-8.3 \%$ ). In patients with mitral stenosis greatest mortality was observed in the group $<50$ years $(2.9 \%)$ and in the case of regurgitation greatest mortality was observed in group aged 5060 years $(6.6 \%)$. Risk factor for mortality in patients

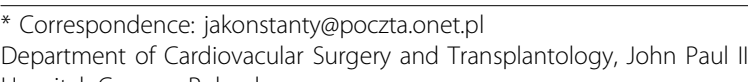

* Correspondence: jakonstanty@poczta.onet.pl
Department of Cardiovacular Surgery and Transplantology, John Paul II Hospital, Cracow, Poland
}

(c) 2013 Konstanty-Kalandyk et al; licensee BioMed Central Ltd. This is an Open Access article distributed under the terms of the Creative Commons Attribution License (http://creativecommons.org/licenses/by/2.0), which permits unrestricted use, distribution, and reproduction in any medium, provided the original work is properly cited. mechanical valve implantantation in patients with acquired valve disease. Journal of Cardiothoracic Surgery 2013 8(Suppl 1):0108.

Submit your next manuscript to BioMed Central and take full advantage of:

- Convenient online submission

- Thorough peer review

- No space constraints or color figure charges

- Immediate publication on acceptance

- Inclusion in PubMed, CAS, Scopus and Google Scholar

- Research which is freely available for redistribution
Cite this article as: Konstanty-Kalandyk et al:: Perioperative results of 